\title{
Methodological Aspects of Assessment of Foreign Economic Activity in Coal Mining Regions
}

\author{
Irina Kudryashova ${ }^{1,{ }^{*}}$, Elena Dolbnya $^{2}$, Natalia Zakharova ${ }^{3}$, and Anastasiya Loginova ${ }^{1}$ \\ ${ }^{1}$ Plekhanov Russian University of Economics, Kemerovo branch, 650992, 39, Kuznetskiy prospect, \\ Kemerovo, Russia \\ ${ }^{2}$ Kemerovo State University, 650000, 6, Krasnaya Street, Kemerovo, Russia \\ ${ }^{3}$ Plekhanov Russian University of Economics, 117997, 36, Stremyanny lane, Moscow, Russia
}

\begin{abstract}
In the article it is considered methodological aspects of assessment of foreign economic activity at the level of Russian regions, it is highlighted advantages and disadvantages of some approaches. It was concluded that at present it is advisable to develop an integrated methodology for assessing the effectiveness of foreign trade activities of the region and its investment attractiveness, which can minimize the disadvantages of existing approaches and comprehensively reflect the ongoing processes in the region in the field of foreign economic activity. The need to assess foreign economic activity in the Russian regions on the basis of the principles of complementarity, cooperation and integration with other regions, generation of synergy, extension of spatially distributed value chains is justified. Application of this methodical approach in regional economy as the effective instrument of modern socially oriented management of processes for exploitation of natural resources, development of science and education, creation of regional infrastructure for support of export-oriented and import-substituting business is offered.
\end{abstract}

\section{Introduction}

In the context of the crisis development of the Russian economy, the most important, and often the only direction of maintaining the stability of domestic business is the entry of enterprises and firms of the Russian Federation into new foreign markets, the intensification of exports is the most important direction of expansion of foreign economic activity at the present stage.

In this regard the study of such categories as "foreign economic activity", "foreign trade activity", "investment activity", "investment potential" and "investment attractiveness of the region" characterizes the international nature of business deserves scientific interest. The definition of directions of improvement and development of foreign economic activity in the region requires adequate assessment of the state of foreign trade and investment activity of economic entities. In modern literature the assessment of foreign trade at the regional level is considered in isolation from the investment activities of the region. According to

\footnotetext{
* Corresponding author: kudrina2007@mail.ru
} 
the authors, these spheres of foreign economic activity cannot be considered separately, the mutual influence of these spheres and the synergistic effect are obvious, which makes it necessary to change conceptual approaches when considering issues of assessment of foreign trade in the Russian regions.

The purpose of this research is to study and update methodological approaches to assessing the foreign trade of the region and its investment attractiveness in managing the spatial development of Russia.

\section{Materials and methods}

The Great Encyclopedia Dictionary gives the following definition of foreign economic activity: "these are foreign trade, investment and other activities, including production cooperation, in the field of international exchange of goods, information, works, services, results of intellectual activity, including exclusive rights to them (intellectual property)" [1]. This economic definition is reflected in the researches of foreign and Russian scientists, legally enshrined, but in turn requires further research, and it is from the point of view of the specifics of its implementation and economic potential not so much at the level of enterprises and firms as at the regional level as the basis of Russian statehood.

It should be noted that very often foreign economic activity in the Russian regions is considered mainly as foreign trade activity, especially in conditions of weak development of the investment component of the regional economy. In this case, there is a substitution of concepts, which is not quite correct. Depending on the involvement of enterprises and firms of the territories in export and import operations, their typology is carried out, the rating of investment attractiveness of the regions is built, which is also due to the scale of development of export and import operations by business participants. At the same time, emphasis is placed on the development of foreign trade in order to attract foreign investment [2-4].

Ishmukhametov N.T. points out that the intensification of foreign economic activity as a factor in the development of the socio-economic situation in the region increases the inflow of foreign investments, the life quality and employment of the population, contributes to budgetary revenues, which ultimately affects the development of the country, its economy, GDP growth [5].

The author identifies a close correlation of the level of economic development in the region with its foreign trade activities and investments from abroad, exploring and assessing the foreign economic potential of the region.

It is true that adequate assessment and understanding of the external economic potential in the region, external and internal factors of its development are the basis for making strategically competent management decisions [6].

Objective and detailed analysis of the foreign economic potential in the region implies: - study of the possibilities for economically defensible export and import increase in trade turnover;

- identification of a list of companies in the region with the highest potential for entry into the export market;

- compilation of a list of perspective goods with a view to expanding their export volumes;

- identification of goods for import specialization of the region;

- analysis of the investment potential to attract investments from abroad [5].

The definition of directions for improvement and development of foreign economic activity at the level of the region requires adequate assessment of the state of foreign trade and investment activity. Often in the scientific literature this assessment is carried out in both directions separately, and as a result a general conclusion is drawn on the current state 
and problems of development in the region without specifying the factors that caused the current situation.

Russian and foreign researchers have developed several different methods of assessing the foreign trade of the region.

We have identified six main methodological approaches to the assessment of foreign trade activities at the regional level [7].

1) The first approach (let's call it "comparative") is based on comparison of characteristics of foreign trade turnover of the region with the country level, assessing the place and role of this Russian region, its localization on the national scale. However, this approach does not assess the contribution of export activities to the economy and social spherical region, especially in relation to the growth rate of its production and profits.

The evaluation of this approach provides a synthesis of the role of foreign trade and local positioning of the region at the national level, without taking into account qualitative indicators, which are taken into account to varying degrees in other methodologies presented below.

2) The second approach ("integral") involves the design of an integral parameter from indicators characterizing the foreign trade of all participants in foreign economic activity. This approach allows for a more comprehensive assessment of foreign trade activities at the regional level, as it uses an integrated assessment by economists, calculated on the basis of key indicators based on algorithmization and economic and mathematical modeling. For example, N. V. Red'kina has developed a methodology for optimizing regional foreign trade activities, which allows to identify and quantify all possible versions for choosing international contracts, their terms, customers, performers, etc. [8].

The disadvantage of this approach is that it does not identify the factors and causes that have affected the economic development of the region.

3) The purpose of the third approach (let's call it "cluster") is to group regions according to various criteria of foreign trade activity. Thus S.N. Bludova developed an algorithm for the formation of regional clusters on the basis of foreign trade activities. First of all, the author proposes to assess the industry specialization of the region and to identify exportoriented and import-oriented industries. Further, the rationality of the export and import structure for export-oriented and import-oriented industries is evaluated, respectively, in order to form the optimal structure of foreign trade turnover. For this purpose the GrubelLloyd coefficient is used, the calculation of which allows to estimate the development level of foreign trade in the country (region) by commodity groups (formula 1):

$$
K=\frac{\Sigma\left(E_{i j}+I_{i j}\right)-\Sigma\left(E_{i j}-I_{i j}\right)}{\Sigma\left(E_{i j}+I_{i j}\right)}
$$

where: $E_{i j}, I_{i j}$ - export and import of country (region) $j$ group of products $i$ [9].

The structure of foreign trade transactions is assessed by S. N. Bludova on the basis of the Comparative Advantage Index (RCA) developed by the French Economic Research Institute and calculated separately by export and import products according to formula 2 . In general, this index practically acts as a factor of localization of exports or imports.

$$
R C A_{u}=\frac{I_{p m j} \times I_{c}}{I_{p} \times I_{c m j}}
$$

where: $I$ - import from the region of $\mathrm{j}$-goods;

$I_{c}$ - total import of the country;

$I_{p}$ - total import of the region;

$I_{c m j}$ - import from the country of $\mathrm{j}$-goods. 
The contribution of each commodity position to the foreign trade balance of the region is calculated by S. N. Bludova according to formula 3, which estimates the comparative advantage of the region in trade in any commodity:

$$
T_{i b}=\frac{1000}{G R P} \times\left[\left(E_{i}-I_{i}\right)-(E-I) \times\left(\frac{E_{i}+I_{i}}{E+I}\right)\right]
$$

where: GRP - gross regional product;

$I_{i}$ - export volume of goods $i$;

$I_{i}$ - import volume of goods $i[10]$.

The disadvantage of this methodology is that it does not allow to fully assess the qualitative parameters of the foreign trade in the region, to identify the main factors of optimization of regional exports.

4) In the fourth approach, the efficiency assessment is carried out on the basis of one or two resulting indicators of export-import activities. This approach, referred to by us as the "method of measuring the balance of foreign trade", shows the geographical orientation of commodity flows to trading partner countries. In their researches E.V. Semenova and O.S. Lukanchenkov, using the coefficient of balance of foreign trade activities (formula 4), try to analyze its effectiveness:

$$
K=\frac{C}{T O}
$$

where: $K$ - coefficient of balanced foreign trade;

$C$ - foreign trade balance;

$T O$ - commodity turnover [11].

This is followed by the calculation of the coefficient of balanced foreign trade for each partner country, and then the combined effectiveness of international trade relations between countries is determined by adding up. The disadvantage of this methodology is that the calculations do not take into account the structural characteristics of foreign trade activities and their commodity nomenclature, which does not allow to fully carry out the analysis that allows to optimize the structure of foreign trade later and to identify the factors and causes of structural imbalance throughout the country. This methodology is used, as a rule, at the national level and is not appropriate for application at the regional level due to different specialization and differentiation of the natural and economic potential of the country.

5) Another methodology for assessing foreign trade at the regional level in the literature is based on the "index" approach developed by S.I. Ul'tan [12].

First of all, key quantitative indicators are calculated, followed by a direct assessment of the foreign trade in the region in a system of key indicators of its economic development, the most important of which is the gross regional product (GRP).

Then, an analysis of the impact of the foreign trade activities in the region on its economic development and financial sustainability is carried out, causal relations are identified and the main conclusions are formulated.

In order to carry out an integrated assessment of regional foreign trade activities, this approach uses key quantitative indicators, grouped into three main categories:

- absolute and relative indicators (indicators of structure, dynamics, comparison) which give a general characteristic of foreign trade in the region;

- indicators of the degree of involvement of a particular region in international trade (export quota, import quota, foreign trade quota, import coverage coefficients of exports, elasticity of foreign trade turnover, international competitiveness, etc.), which characterize the degree of foreign trade activity in the region; 
- index indicators (net terms of trade index, gross terms of trade index, income terms of trade index, Grubel-Lloyd index, etc.), which give a more detailed assessment in certain areas of foreign trade research.

In our view, on the basis of the analysis of quantitative indicators, it is possible to draw the main conclusions on the effectiveness of the implementation of foreign trade activities, to provide a general description and to identify the constraints on the economic development of the region and the reasons for their impact, which is an unconditional advantage of this approach compared to the ones discussed earlier. This method should be used in the analysis of non-resource exports of the region as the most important direction of diversification of foreign economic activity and optimization of the economic structure on a regional and national scale.

6) E.E. Kolchinskaya proposes its approach to the assessment of the foreign trade in the region, the purpose of which is related to the manifestation of the relationship between foreign trade activities and the economic development of the territory [13].

This approach, which we call "multiplier", begins with the calculation of basic quantitative indicators, then directly estimates the foreign trade in the region in terms of the key indicators of its economic development, the most important of which is the gross regional product (GRP). And in the conclusion, an analysis of the impact of foreign trade activities of the region, assessment of its multiplier effect on economic development, financial stability of the region is carried out, causal relations are identified and the main conclusions are formulated.

In our opinion, this "multiplier" approach most fully characterizes not only the place and role of foreign trade in the regional economy, but also reflects the participation of the region in the international division of labour.

The latter two approaches - "index" and "multiplicative" - provide a comprehensive assessment of the performance of foreign trade activities at the level of the region, however, miss the influence of investment factors that increase the competitiveness of domestic products in world markets, and the expansion of positioning of both the region and the country in global processes.

In our view, investment cooperation with foreign partners is a very important factor in stimulating foreign trade in the region, the effectiveness of which is usually assessed on the basis of an analysis of the investment attractiveness of the region. By means of this analysis, both the foreign investor and the state regulators can adequately assess the correctness of an investment decision not only for the purpose of a specific project, but also in the light of the impact on other types of foreign economic and production and economic activities.

At present, there is no generally accepted methodology in Russian legislation to determine the investment attractiveness of the Russian region. At the same time, the latter is characterized by two components: investment climate and investment risk. It is these conditions that mainly determine low or high investment activity in a region or a country.

Economic literature and the media use a wide variety of methods to assess investment attractiveness at the national and regional levels, which are developed by researchers and rating agencies alike.

One of the most common is the approach that defines investment attractiveness as a set of socio-political, natural-economic and psychological characteristics. An integral indicator of investment climate reliability $(\mathrm{K})$ is used to estimate attractiveness, which is calculated as a weighted average arithmetic value of private indicators according to formula 5:

$$
K=\frac{\kappa_{1} \times l_{1}+\kappa_{2} \times l_{2}+\cdots+\kappa_{n} \times l_{n}}{\sum_{i=1}^{n} l_{i}}
$$

where: $K_{l}, K_{2}, K_{n}$ - private indicators (financial, economic, political indicators); 
$l_{1}, l_{2, \ldots} l_{n}-$ weight values of private indicators [14].

The value of $\mathrm{K}$ is between 0 and 10 . The higher the value of the integral indicator of reliability of the investment climate, the more favorable the climate the region has. The main disadvantage of this approaches is the blurred estimation of the constituent indicators and the ambiguity, and often the close intercomparison and intercomparence of the evaluated characteristics.

In practice, methods based on the assessment of the investment climate rating are widely used when there is an interconnected assessment of the two components of potential and risk.

Table 1 provides a comparative description of the main approaches to assessing the investment climate, based on an analysis of investment potential, risks and factors affecting them [14].

Table 1. Main approaches to assessing the investment climate of the region [14-15].

\begin{tabular}{|c|c|c|}
\hline Approach & Advantages of a method & $\begin{array}{c}\text { Disadvantages of a } \\
\text { method }\end{array}$ \\
\hline «Narrowed» & $\begin{array}{l}\text { - takes into account the main } \\
\text { purpose of business activity - } \\
\text { profit generation and return of } \\
\text { invested funds; } \\
\text { - possibility to use for } \\
\text { investment climate research } \\
\text { in various economic systems }\end{array}$ & $\begin{array}{l}\text { - doesn't detect quite } \\
\text { important and objective } \\
\text { links of investment } \\
\text { activity and potential } \\
\text { with resources, } \\
\text { innovation processes } \\
\text { and level of economic } \\
\text { stability in the regions }\end{array}$ \\
\hline $\begin{array}{l}\text { «Expanded», } \\
\text { multifactorial }\end{array}$ & $\begin{array}{l}\text { - use of statistics that offset } \\
\text { the subjectivity of } \\
\text { assessments; } \\
\text { - differential treatment of } \\
\text { different levels of the } \\
\text { economy; } \\
\text { - striving to provide the } \\
\text { widest possible overview of } \\
\text { all possible sources of } \\
\text { investment }\end{array}$ & $\begin{array}{l}\text { - labour-intensive use in } \\
\text { practice }\end{array}$ \\
\hline «Risky» & $\begin{array}{l}\text { - use of statistics that offset } \\
\text { the subjectivity of } \\
\text { assessments; } \\
\text { - interrelation between } \\
\text { investment climate and } \\
\text { investment risk categories }\end{array}$ & $\begin{array}{l}\text { - labour-intensive use in } \\
\text { practice }\end{array}$ \\
\hline
\end{tabular}

Another method of assessing investment attractiveness is based on the definition of economic and risk components (formula 6):

$$
\mathrm{K}=\mathrm{k}_{1} \times\left(1-\mathrm{k}_{2}\right)
$$

where: $K$ - indicator of investment attractiveness of the region, in shares of the unit;

$k_{1}-$ economic component, in shares of the unit;

$k_{2}$ - risk component, in shares of the unit [14].

The economic component is calculated as the ratio of profit from investment to investment by formula 7 : 


$$
k_{1}=\frac{(G R P \times(1-D) \times(1-T)-I)}{I}
$$

where: GRP - gross regional product;

$D$ - budget deficit, in shares of the unit (ratio of state budget deficit to GRP);

$T$ - average tax rate;

$I$ - volume of investment.

The risk component is an estimate of the aggregate risk level and is calculated according to formula 8:

$$
k_{2}=\frac{\sum_{i=1}^{n} p_{i} \times j_{i}}{\sum_{i=1}^{n} j_{i}}
$$

where: $\mathrm{n}$ - number of indicators;

$p_{i}$ - characteristic of an indicator;

$j_{i}$ - indicator weight.

This methodology takes into account both qualitative and quantitative indicators. The set of quantitative indicators is ranked by the degree of influence on the indicator of the volume of investments in fixed assets, which characterizes investment activity in the region, the most significant indicators are identified for calculation of the risk component. The interrelation between investment volume and investment attractiveness indicators is determined by means of correlation analysis.

In order to compare quantitative and qualitative indicators and to use them in further calculations, a point scale is used, according to which each indicator is assigned its own weight factor based on the method of priorities. Regions are classified as follows depending on the value of the investment attractiveness indicator:

$K>0.4$ - high investment attractiveness;

$0.2<K<0.4$ - investment attractiveness above average;

$0.1<K<0.2$ - average investment attractiveness;

$0.05<K<0.1$ - investment attractiveness below average;

$K<0.05$ - low investment attractiveness.

The Institute of Economics of Russian Academy of Sciences has developed its methodology for assessing the investment attractiveness of the region, taking into account the influence of such factors as:

- natural and resource potential;

- demographic potential;

- economic potential;

- level of economic development;

- economic activity;

- standard of living of the population;

- state of regional finance;

- degree of implementation of economic reforms;

- political voter turnout;

- sustainability and influence of regional structures [15].

The total weighted assessment of the investment climate by region is according to formula 9:

$$
\mathrm{CO}=\sum_{\mathrm{n}}^{\mathrm{k}} \mathrm{cb}_{\mathrm{n}} \times \mathrm{W}_{\mathrm{n}}
$$

where: $\mathrm{CO}$ - summary weighted assessment of investment climate;

$\mathrm{cb}_{\mathrm{n}}$ - average score of the $\mathrm{n}$-factor for the region;

$\mathrm{W}_{\mathrm{n}}$ - weight of the $\mathrm{n}$-factor; 
$\mathrm{k}$ - number of factors.

According to the results of calculations, the line of regions, ranked by investment attractiveness, is built.

Currently, each region has its own concept and programme of foreign economic activity, but not all of these instruments are effective and often declarative, without a real application mechanism.

\section{Results and discussion}

In modern literature the assessment of foreign trade at the regional level is considered in isolation from the investment activities of the region. According to the authors, these spheres of foreign economic activity cannot be considered separately, the mutual influence of these spheres and the synergistic effect are obvious, which makes it necessary to change conceptual approaches when considering issues of assessment of foreign trade in the Russian regions.

The definition of directions of improvement and development of foreign economic activity in the region requires adequate assessment of the state of foreign trade and investment activity of economic entities.

When considering methodological aspects of assessment of foreign economic activity at the level of Russian regions, the authors highlighted advantages and disadvantages of some approaches. It was concluded that at present it is advisable to develop an integrated methodology for assessing the effectiveness of foreign trade activities of the region and its investment attractiveness, which can minimize the disadvantages of existing approaches and comprehensively reflect the ongoing processes in the region in the field of foreign economic activity.

As a solution to this problem, it is proposed to carry out comprehensive monitoring of foreign economic activity, both at the regional level and at the level of the whole country, taking into account strengths and weaknesses, identification of potential growth points and perspective directions of development to intensify the foreign economic potential of the region. The need to assess foreign economic activity in the Russian regions on the basis of the principles of complementarity, cooperation and integration with other regions, generation of synergy, extension of spatially distributed value chains is justified.

Application of this methodical approach in regional economy as the effective instrument of modern socially oriented management of processes for exploitation of natural resources, development of science and education, creation of regional infrastructure of support of export-oriented and import-substituting business is offered.

\section{Conclusions}

The study showed that at present there is no single universal method of assessing the effectiveness of foreign trade activities of the region and its investment attractiveness in world and Russian practice. Russian and foreign researchers offer different methods of assessing foreign economic activity, but each of them has its advantages and disadvantages. In this regard, it is advisable to develop an integrated methodology that can minimize the disadvantages of existing approaches and comprehensively reflect the ongoing processes in the region in the field of foreign economic activity.

Summarizing the results of the studies carried out, it can be concluded that the solution to this problem is to carry out integrated monitoring of foreign economic activity, both at the regional level and at the level of the country as a whole, and to further build the corresponding program for each specific region taking into account strengths and 
weaknesses, potential growth points and perspective directions of development to intensify the foreign economic potential of the region. Taking into account this thesis, according to the authors, the assessment of foreign economic activity in the Russian regions should be carried out on the basis of the principles of complementarity, cooperation and integration with other regions, generation of synergy, extension of spatially distributed value chains.

The application of this methodological approach in the regional economy taking into account the inextricably functioning foreign trade and investment components, can become an effective tool for modern socially oriented management of the processes for exploitation of natural resources, development of science and education, creation of regional infrastructure to support export-oriented and import-substituting business.

\section{References}

1. The Great Encyclopedic Dictionary. URL: http://www.vedu.ru/bigencdic/

2. A. Barkovskiy, A. Komissarov, Forecasting problems, 3, 129-142 (2000)

3. A. Linetskiy, Journal of the Ural State University of Economics, 1:33, 73-78 (2011)

4. A. Tatarkin, Economy of region, 2, 5-22 (2005)

5. N. Ishmukhametov, Student's forum, 9:30 (2018)

6. A. Rudakova, Modern problems of science and education, 1:1, 19-21 (2015)

7. T. Uskova, S. Dedkov, T. Smirnova, R. Selimenkov, V. Asanovich, Interregional cooperation as a factor of integration processes between the Russian Federationand the Republic of Belarus (Institute of Social and Economic Development of the Territories of the Russian Academy of Sciences, Vologda, 2011)

8. N. Red'kina, Structural CASE-analysis of regional foreign trade processes (on the materials of Stavropol Krai) (STU, Stavropol, 2004)

9. H. Grubel, P. Lloyd, Intra Industry trade: The Theory and Measurement of internationality trade in Differentiated Products (Wiley, New York, 1975)

10. S. Bludova, Voprosy statistiki, 11, 65-66 (2002)

11. E. Semenova, O. Lukanchenkov, Economy of the North-West: Issues and Prospects of Development, 2:4, 62-66 (2000)

12. S. Ul'tan, Herald of Omsk University. Economics, 3, 38-49 (2012)

13. E. Kolchinskaya, S. Rastvortseva, Research Bulletin of Belgorod State University. Economics. Informatics, 22-1:165 (2013)

14. I. Leonova, Bulletin of RSUH, 10, 120-126 (2011)

15. R. Khusnullin, Herald of Kazan Technological University, 5, 65-71 (2009) 